\title{
PENGARUH FAKTOR DISTRESS RISK DALAM MENJELASKAN EFEK ANOMALI MOMENTUM
}

\author{
Bertha Silvia Sutejo \\ Universitas Surabaya
}

\begin{abstract}
The objective of this research was to study the effect of momentum anomaly and distress risk. This research also examines the different market effects on potential relationship between momentum and distress risk and prepare indirect empirical evidence on EMH in Indonesia. Sample of this research was based on manufacturing companies listed in Jakarta Stock Exchange from July 1992 - June 2003. The statistical method used to test the hypothesis was regression analysis. The study results were as follows: first, the result provides no support for the hypothesis that the distress risk can explain momentum effect in stock return; second, the result also provides no support for the hypothesis that there is no different influence on potential relationship between momentum and distress risk at bullish market or bearish market. This study found that distress risk and momentum make the size and B/M have a positive relationship with stock return on bullish market. But distress risk and momentum make size and $B / M$ have a negative relationship with stock return on bearish market.
\end{abstract}

Keywords: Distress Risk, Momentum Effect, Bullish Market, Bearish Market, and EMH (Efficient Market Hypothesis)

\section{PENDAHULUAN}

Investor membutuhkan strategi dan momentum yang tepat ketika memilih saham agar dapat menghasilkan return yang tinggi. Momentum menunjukkan kecenderungan saham yang memiliki performance baik maka di masa mendatang akan terus berlanjut baik, begitu pula sebaliknya jika saham memiliki performance buruk maka di masa mendatang juga akan berlanjut buruk (Jones, 2004). Fenomena anomali momentum menimbulkan sebuah teka-teki yang menentang efisiensi pasar dalam bentuk lemah. Terdapat tiga penjelasan mengenai terjadinya return yang abnormal tersebut. Pertama, abnormal return terjadi karena data mining. Kedua, menyatakan bahwa abnormal return merupakan kompensasi yang wajar untuk risiko dan atau biaya transaksi (Berk et al., 1999; Griffin dan Lemmon, 2002; Griffin dan Martin, 2003; Agarwal dan Taffler, 2005). Penjelasan ketiga didasarkan pada psikologi investor dalam menanggapi informasi yang ada di pasar dan keyakinan bahwa pasar tidak efisien sehingga terjadi overreaction atau underreaction (Jegadeesh dan Titman, 1993, Barberis et al., 1998; Hong dan Stein, 1999)

Kondisi pasar yang menggairahkan atau lesu juga mempengaruhi profit momentum. Situasi ekonomi menjadi reward untuk risiko harga dari siklus bisnis. Pengaruh pasar yang berbeda pada saat bullish atau bearish dalam market pricing mengakibatkan tingginya risiko kegagalan dan akhirnya menyebabkan perusahaan mengalami kesulitan keuangan. Premium risiko kebangkrutan berubah-ubah sesuai dengan situasi ekonomi. Perusahaan yang distress seharusnya lebih sensitif terhadap kondisi ekonomi karena return saham mereka dipengaruhi oleh faktor makroekonomi seperti masalah likuditas, kredit, dan kualitas. Jagannatahan dan Wang (1996) serta Ang dan Chen (2002) memperlihatkan bahwa faktor risiko tidaklah stasioner tetapi berubah-ubah sepanjang waktu. Fabrozi dan Francis, Bhardwaj dan Brooks seperti dikutip Tandelilin (2001) juga mengatakan bahwa risiko sistematis (beta) 
saham sebagai komponen penting untuk mengestimasi return suatu saham tidaklah stasioner dari waktu ke waktu, sehingga perlu disesuaikan dengan kondisi pasar yang sedang terjadi. Penelitian Ang dan Chen (2002) menemukan bahwa korelasi antara return portofolio dan return pasar lebih tinggi untuk saham berukuran kecil dan B/M tinggi pada down market dibandingkan ketika up market. Zhang dan Petkova (2005) juga menemukan bahwa beta untuk saham berukuran kecil dan B/M tinggi akan berubah-ubah secara positif dengan expected risk premium. Penelitian Bharwaj dan Brooks (1993), Ahmed dan Loxkwood (1998), Howton dan Peterson (1998), Fabozzi dan Francis (1997), Wiggins (1992), Vennet dan Crombez (1997) seperti yang dikutip oleh Tandelilin (2001), menunjukkan bukti empiris mengenai perbedaan signifikan mengenai risiko sistematis pada bull maket dan bear market.

Selama ini belum banyak penelitian yang meneliti secara langsung hubungan potensial antara momentum dan distress risk. Hasil penemuan empiris Agarwal dan Taffler (2005) menemukan bahwa efek anomali momentum dapat dijelaskan oleh faktor financial distress. Mereka menunjukkan bahwa saham yang distress adalah sahamsaham perusahaan yang memiliki kinerja buruk di masa lalu dan continous return yang dihasilkan biasanya rendah. Anomali-anomali yang menyebabkan abnormal return bukan semata-mata akibat dari perilaku investor dalam menanggapi informasi yang ada tetapi merupakan kompensasi dari risiko. Agarwal dan Taffler (2005) berusaha mendukung hipotesis pasar yang efisien.

Anomali-anomali terhadap pasar efisien masih terus diperdebatkan. Agarwal dan Taffler (2005) memberikan dukungan bahwa pasar masih efisien, anomali momentum return saham dapat dijelaskan oleh distress risk. Apakah kondisi pasar modal di Indonesia juga tergolong efisien? Apakah abnormal return atau return continous yang selama ini ada juga dapat dijelaskan dengan distress risk? Berdasarkan isu tersebut, peneliti termotivasi untuk melakukan pengujian secara empiris penemuan Agarwal dan Taffler tersebut pada pasar modal Indonesia. Penelitian ini bertujuan untuk menguji apakah distress risk dapat menjelaskan efek anomali momentum atau return continuation dalam return saham? Proksi risiko kebangkrutan yang digunakan oleh peneliti adalah model z-score Altman yang sudah disesuaikan dengan kondisi pasar di Indonesia. Analisis penelitian diperluas dengan mempertimbangkan situasi waktu yang berubah-ubah (time varying) dari distress risk premia dan return momentum sebagai moderating variable. Penelitian yang dilakukan ini berusaha memberikan dukungan terhadap Efficient Market Hypothesis (EMH) di Indonesia.

\section{TINJAUAN LITERATUR DAN PENGEMBANGAN HIPOTESIS}

\section{1. Pengertian Momentum, Hubungan Momentum dan Faktor Risiko}

Momentum dalam return saham menyatakan kecenderungan saham yang memiliki kinerja baik selanjutnya akan memiliki kinerja yang baikjuga, sebaliknya apabila memiliki kinerja buruk selanjutnya juga akan tetap memiliki kinerja buruk (Jones, 2004). Jegadeesh dan Titman (1993) serta Moskowitz dan Grinblatt (1999) menyatakan bahwa strategi momentum adalah strategi membeli past winning stock dan menjual past losing stock. Jegadeesh dan Titman (1993) mengadakan penelitian yang pertama kali menguji efek momentum dan menunjukkan hasil bahwa strategi perdagangan membeli saham terjadi ketika nilai suatu saham naik selama 6 - 12 bulan dan menjual saham yang merugikan pada perioda waktu tersebut agar mendapatkan abnormal return yang superior.

Teori CAPM menyatakan bahwa setiap investasi membawa dua risiko yang berbeda, yaitu risiko sistematik yang diukur oleh beta, dan risiko tidak sistematik. CAPM memiliki asumsi bahwa para investor memiliki portofolio yang terdiversifikasi dengan baik di mana satu-satunya penentu risiko yang penting adalah risiko systematic (beta). Tahun 1992 dan 1993, Fama dan French menambahkan variabel size dan rasio book-to-market equity untuk menjelaskan variasi dalam return saham. Tahun 1996, Fama-French kembali menguji bahwa model threefactor mereka dapat menjelasan anomali-anomali yang ditemukan dalam model asset pricing. Namun ternyata model three-factor Fama-French masih memiliki kekurangan. Kekurangan model tersebut menyangkut anomali efek momentum. Efek momentum ini berbeda dari efek value yang ditangkap oleh book-to-market equity dan rasio harga yang lain. Efek momentum ini tidak dapat dijelaskan oleh model three-factor Fama-French.

Menurut Hong dan Lee (2003), terdapat dua penjelasan berbeda untuk menjelaskan efek momentum. Salah satu penjelasan menyatakan bahwa saham dengan momentum yang tinggi cenderung menghasilkan return di masa 
depan yang tinggi. Hal ini disebabkan karena secara fundamental mereka lebih berisiko sehingga mengharapkan expected return yang tinggi pula (seperti yang dikemukakan oleh penelitian Conrad dan Kaul (1998), Moskowitz dan Grinblatt (1999)). Penjelasan lain didasarkan pada teori keperilakuan (behavioral theories) yang memprediksi reaksi investor (under-reaction atau over-reaction) terhadap berita-berita fundamental (seperti pengumuman dividen atau earning).

Terdapat pertentangan mengenai paradigma market efficiency selama akhir tahun 1970-an. Penelitian yang mendukung hipotesis pasar efisien menyatakan bahwa abnormal return melawan pasar efisien merupakan bukti yang tidak dapat dipercaya. Mereka menyatakan bahwa return yang abnormal merupakan kompensasi yang wajar dari risiko. Variabel spesifik perusahaan seperti size, book-to-market, earning-price, debt-to-equity, berkorelasi dengan leverage atau distress merupakan instrumen yang sesuai untuk risiko beta yang tidak dapat ditangkap dan juga menjelaskan excess return dalam cross-section.

Konsep financial distress kemudian berkembang dalam literatur asset pricing untuk menjelaskan pola anomali-anomali lain dalam cross-section dari stock return (Campbell et. al., 2004). Ide dasarnya adalah bahwa perusahaan yakin memiliki risiko yang meningkat ketika mereka gagal untuk memperbanyak obligasi keuangan mereka. Oleh karena itu kemudian mereka akan menuntut premium untuk risiko tersebut. Risk premium tersebut memberikan kontribusi hampir separuh dari profit momentum.

Kegagalan dalam dunia bisnis dapat diakibatkan oleh dua faktor, yaitu faktor ekonomi dan faktor finansial. Faktor ekonomi meliputi kelemahan industri dan lokasi yang buruk, sedangkan faktor finansial meliputi utang yang terlalu banyak dan modal yang tidak efisien (Brigham dan Daves, 2004). Faktor finansial inilah yang dapat menimbulkan perusahaan mengalami financial distress. Financial distress merupakan proses jangka panjang dan memiliki dampak pada struktur modal, kebijakan investasi, dan kinerja perusahaan (Kahl, 2002). Dalam mendapatkan sumber financial, perusahaan tidak lepas dari bahaya financial distress.

Suatu investasi memang akan menghasilkan return yang maksimal, namun hal ini seiring pula dengan besarnya risiko yang akan diterimanya. Teori investasi mengemukakan bahwa semua keputusan investasi itu merupakan trade off antara expected return dan risk (Jones, 2004). Tetapi, tidak semua investasi yang berisiko tinggi akan menghasilkan return yang tinggi pula. Salah satu faktor yang menyebabkan hal tersebut adalah penyesuaian posisi solvency perusahaan. Bagi investor, penyesuaian posisi solvency perusahaan bukanlah pekerjaan yang mudah (Agarwal dan Taffler, 2005). Perilaku pasar dan psikologis investor dalam membuat keputusan mempengaruhinya (De Bondt dan Taffler, 1985). Perbedaan tentang information asymmetric mengakibatkan distress risk bagi perusahaan (Griffin dan Lemmon, 2002; Ng, 2004). Berdasarkan hal tersebut maka hipotesis pertama yang dikemukakan dalam penelitian ini adalah sebagai berikut:

H1. Distress risk dapat menjelaskan efek anomali momentum atau return continuation pada return saham.

\section{2. Pengaruh Bullish Market dan Bearish Market terhadap Hubungan Momentum dan Faktor Risiko}

Perusahaan yang distress atau kinerjanya buruk seharusnya sensitif terhadap kondisi ekonomi yang umum seperti credit aqueezes, liquidity crunches, atau perang kualitas. Daniel, Hirshleiferm dan Subrahmanyam (1998) seperti dikutip oleh Tandelilin (2001) mengembangkan teori untuk memprediksi perbedaan profit momentum pada berbagai situasi pasar. Semenjak investor menahan sejumlah posisi long equity market dan menaikkan harga pasar, investor menjadi overconfidence dan overreaction terhadap up market karena menghasilkan profit momentum jangka pendek yang tinggi.

Kondisi suatu pasar modal terbagi menjadi dua, yaitu up (bullish) market dan down (bearish) market. Menurut Jones (1998) seperti dikutip oleh Tandelilin (2001: 261-262), pengertian bullish market adalah

...suatu kecenderungan pergerakan naik (upward trend) yang terjadi di pasar modal. Hal ini ditandai kecenderungan peningkatan harga-harga saham (indeks pasar) baru yang mampu menembus nilai atas harga (indeks pasar) sebelumnya, ataupun kalau ada penurunan harga, tidak sampai melewati batas harga (indeks) terbawah yang tejadi sebelumnya. 
Sedangkan istilah bearish market diartikan sebaliknya, yaitu:

...kecenderungan pergerakan turun (downward trend) yang terjadi di pasar modal. Indikasinya adalah jika harga (indeks) baru gagal menembus batas tertinggi harga sebelumnya, atau jika penurunan harga (indeks) yang terjadi mampu menembus batas bawah harga (indeks) yang terjadi sebelumnya.

Seperti yang telah dijelaskan dalam model CAPM bahwa risiko sistematis dianggap relevan dan mempengaruhi besarnya expected return dari suatu aset (Arif dan Johnshon (1990); Jones (1998) seperti dikutip oleh Tandelilin (2001)). Risiko sistematis merupakan risiko yang tidak bisa dikurangi meskipun dengan melakukan diversifikasi investasi pada berbagai jenis aset. Risiko ini terkait dengan pengaruh faktor makro ekonomi maupun politis yang sulit dikendalikan, yang mempengaruhi pasar.

Kondisi pasar (bullish atau bearish) tersebut akan mempengaruhi beta (risiko sistematis) saham sebagai komponen penting untuk mengestimasi return suatu saham yang tidaklah selalu bersifat stasioner dari waktu ke waktu (Tandelilin, 2001). Oleh karena itu, diperlukan upaya penyesuaian terhadap kondisi pasar yang sedang terjadi. Perhitungan risiko sistematis secara terpisah pada saat pasar sedang bullish dan bearish perlu dilakukan untuk mengantisipasi perubahan kondisi pasar yang tejadi. Jadi jika risiko sistematis suatu saham berubah maka return yang disyaratkan terhadap saham tersebut juga perlu disesuaikan (Vennet dan Crombez (1997) seperti dikutip Tandelilin (2001)). Penyesuaian juga perlu dilakukan agar keputusan investor tepat dan kerugian yang harus ditanggung investor dapat dihindari. Tingginya risiko kegagalan (default risk) pada perusahaan yang kesulitan keuangan menyebabkan perlu melihat efek market pricing yang berbeda pada kondisi pasar bearish atau bullish. Kondisi pasar yang berbeda akan mengakibatkan perolehan return yang berbeda pula. Perusahaan yang kesulitian keuangan lebih berprospek pada perioda tingkat pertumbuhan ekonomi tinggi (Agarwal dan Taffler, 2005). Berdasarkan hal tersebut maka hipotesis kedua yang dikemukakan dalam penelitian ini adalah sebagai berikut:

H2. Terdapat perbedaan pengaruh distress risk terhadap efek momentum pada kondisi bullish market dan bearish market.

\section{METODA PENELITIAN}

\section{1. Data dan Sampel}

Penelitian ini menggunakan data mengenai harga penutupan saham bulanan (monthly closing price), market capitalization, indeks harga saham gabungan (IHSG) sebagai proksi untuk menghitung return pasar, dan suku bunga Bank Indonesia (SBI) 1 bulan sebagai proksi risk-free rate. Data tersebut diperoleh dari Indonesia Capital Market Directory (ICMD), www.BI.go.id, www.jsx.co.id, www.indoexchange.com. Periode pengamatan dalam penelitian ini adalah Juli 1992 hingga Juni 2003.

Penelitian ini menggunakan sampel saham-saham yang terdaftar di Bursa Efek Jakarta yang dipilih dengan menggunakan berbagai kriteria seperti: (1) perusahaan manufaktur yang pernah dan atau masih terdaftar di Bursa Efek Jakarta dan sahamnya diperdagangkan secara aktif antara tahun 1990 sampai tahun 2003, (2) perusahaan harus melaporkan laporan keuangannya secara lengkap dan tercatat di Capital Market Directory, (3) market capitalization (MC) paling sedikit 12 bulan observasi dengan nilai kapitalisasi pasar akhir Juni yang positif, (4) nilai B/M akhir Desember yang positif, dan (5) perusahaan harus list paling sedikit dua tahun sebelum formulasi portofolio untuk persyaratan data bagi estimasi beta. Berdasarkan kriteria pemilihan sampel tersebut selama periode pengamatan, rata-rata perusahaan yang menjadi sampel ada 103 perusahaan setiap tahunnya.

\section{2. Pengukuran Variabel}

Pengukuran varaiabel dalam penelitian ini adalah sebagai berikut:

1. Return bulanan dihitung dengan menggunakan rumus dengan closing price saham i saat ini dikurangi dengan closing price saham i perioda lalu dibagi dengan closing price saham I periode lalu. Setelah didapat return bulanan selanjutnya dihitung rata-rata dari return selama 12 bulan. Perhitungan ini dilakukan setiap tahun pada setiap portofolio yang terbentuk. 
2. Beta portofolio diestimasi dengan meregresikan excess return bulanan selama 24 bulan sebelumnya (sebelum pembentukan portofolio) pada masing-masing portofolio dengan market return pada equallyweighted market index. Portofolio beta menggunakan metoda Dimson (1979) dengan one lead dan one lag untuk mengurangi masalah dalam thin trading.

3. Market Capitalization dihitung dari harga dikalikan dengan jumlah lembar saham. Book-to-Market (B/M) ratio dihitung equity per share dibagi dengan closing price. Momentum dihitung dari rata-rata bulanan raw return selama 12 bulan yang lalu.

4. Distress risk dihitung menggunakan model yang diperoleh dari penelitian Likumahwa (2004) sebagai berikut: $Z=-0,855+0,773(\mathrm{X} 1)+17,992(\mathrm{X} 2)$ dengan X1 adalah Working Capital / Total Assets, X2 adalah Earning Before Interest and Tax / Total Asset. Batasan perusahaan mengalami kegagalan atau tidak adalah sebagai berikut: jika Z-score $>0$, berarti diprediksi tidak gagal (tidak bangkrut); jika Z-score $<0$, berarti diprediksi akan gagal (bangkrut).

\section{3. Prosedur Pembentukan Portofolio}

Prosedur pembentukan portofolio dalam penelitian ini adalah sebagai berikut meranking perusahaan berdasarkan nilai beta setiap akhir bulan Juni dan mengelompokannya dalam dua portofolio, yaitu perusahaan yang memiliki nilai beta tinggi dan perusahaan yang memiliki nilai beta rendah. Setelah itu, perusahaan diranking lagi berdasarkan nilai market capitalization setiap akhir bulan Juni dan mengelompokkannya ke dalam dua portofolio, yaitu perusahaan yang memiliki market capitalization tinggi dan yang memiliki market capitalization rendah. Terakhir, perusahaan diranking dalam B/M menggunakan nilai B/M akhir bulan Desember dan dikelompokkan dalam dua portofolio, yaitu highest (perusahaan dengan B/M tertinggi) dan lowest (perusahaan dengan B/M terendah). Pembentukan portofolio ini dilakukan setiap tahun pada akhir Juni tahun $t$ dengan menggunakan informasi nilai beta koreksi akhir Juni tahun $\mathrm{t}$, nilai kapitalisasi pasar akhir Juni tahun $\mathrm{t}$, nilai B/M akhir Desember $\mathrm{t}-1$, rata-rata return 12 bulan lalu (Juli t-1 sampai Juni t), dan nilai z-score akhir tahun $\mathrm{t}$.

\section{4. Model Penelitian, Teknik Pengujian Hipotesis dan Definisi Operasional}

Teknik pengujian dalam penelitian ini menggunakan multivariate regression analysis. Penelitian ini menggunakan model dan langkah analisis sebagai berikut:

1. Pengujian distress risk dapat menjelaskan return continuation (momentum) dalam return saham

Langkah pertama me-run data dengan model 1a regresi berikut ini.

$$
\mathrm{R}_{\mathrm{it}}-\mathrm{R}_{\mathrm{Ft}}=\alpha_{i t}+\gamma_{1 t} \beta_{i t-1}+\gamma_{2 t} \ln \left(\text { size }_{i t-1}\right)+\gamma_{3 t} \ln \left(B / M_{i t-1}\right)+\gamma_{4 t} M_{o m_{i t-1}}+\varepsilon_{i t}
$$

Hipotesis Statistik untuk model tersebut adalah:

$H_{0}: \gamma_{4 t}=0$

$\mathrm{H}_{1}: \gamma_{4 \mathrm{t}}>0$

Kemudian langkah ke-2 me-run data dengan model $1 \mathrm{~b}$ :

$$
\begin{aligned}
\mathrm{R}_{\mathrm{it}}-\mathrm{R}_{\mathrm{Ft}}= & \alpha_{i t}+\gamma_{1 t} \beta_{i t-1}+\gamma_{2 t} \ln \left(\text { size }_{i t-1}\right)+\gamma_{3 t} \ln \left(B / M_{i t-1}\right)+\gamma_{4 t} \text { Mom }_{i t-1} \\
& +\gamma_{5 t} z_{i t-1}+\varepsilon_{i t}
\end{aligned}
$$

Hipotesis Statistik untuk model tersebut adalah:

$\mathrm{H}_{0}: \gamma_{5 \mathrm{t}}=0$

$\mathrm{H}_{1}: \gamma_{5 \mathrm{t}}<0$

Keterangan Model adalah sebagai berikut:

$\mathrm{R}_{\mathrm{it}} \quad=$ equally-weighted return pada portofolio i selama bulan $\mathrm{t}$.

$\mathrm{R}_{\mathrm{Ft}} \quad=\mathrm{SBI} 1$ bulan pada awal bulan $\mathrm{t}$

$\beta_{i t-1}=$ beta dari portofolio i diestimasi pada waktu formulasi portofolio. 


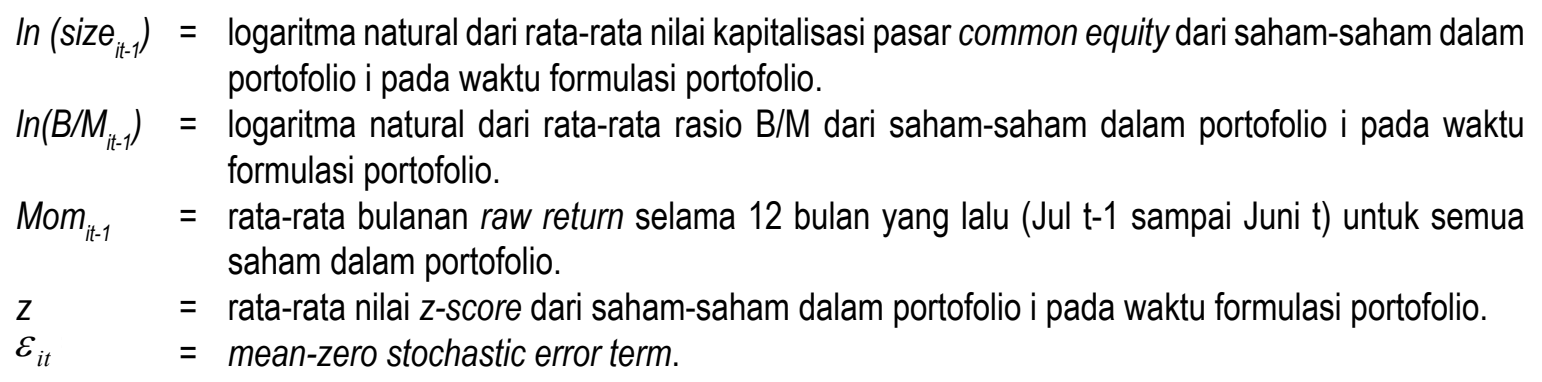

2. Pengujian perbedaan hubungan efek momentum dan distress risk pada kondisi bullish market atau bearish market

Pengujian varibael moderating kondisi pasar (bearish atau bullish) dilakukan dengan langkah awal mengklasifikasikan kondisi pasar bullish dan bearish berdasarkan median (nilai tengah). Pasar bullish jika excess market return lebih tinggi dibandingkan mediannya selama perioda pengamatan. Pasar bearish jika excess market return lebih rendah dibandingkan mediannya selama perioda pengamatan. Setelah penentuan pasar maka dilanjutkan dengan me-run data dengan menggunakan model berikut:

Hipotesis Statistik untuk model 2a tersebut adalah:

$\mathrm{H}_{0}: \mu_{4 \mathrm{t}}=\ell_{4 t} \quad \mathrm{H}_{1}: \mu_{4 \mathrm{t}} \neq \ell_{4 t} \quad$ dengan $\mu:$ kondisi pasar bullish

$\ell:$ kondisi pasar bearish

Kemudian langkah ke-2 me-run data dengan model $2 \mathrm{~b}$ :

$$
\begin{aligned}
\mathrm{R}_{\mathrm{it}}-\mathrm{R}_{\mathrm{Ft}}= & \alpha_{i t}+\mu_{1 t} \beta_{i t-1}+\mu_{2 t} \ln \left(\text { size }_{i t-1}\right)+\mu_{3 t} \ln \left(B / M_{i t-1}\right)+\mu_{4 t} \text { Mom }_{i t-1} \\
& +\mu_{5 t} z_{i t-1}+\varepsilon_{i t} \\
\mathrm{R}_{\mathrm{it}}-\mathrm{R}_{\mathrm{Ft}}= & \alpha_{i t}+\ell_{1 t} \beta_{i t-1}+\ell_{2 t} \ln \left(\text { size }_{i t-1}\right)+\ell_{3 t} \ln \left(B / M_{i t-1}\right)+\ell_{4 t} M_{o m}+\varepsilon_{i t-1} \\
\mathrm{R}_{\mathrm{it}}-\mathrm{R}_{\mathrm{Ft}}= & \alpha_{i t}+\ell_{1 t} \beta_{i t-1}+\ell_{2 t} \ln \left(\text { size }_{i t-1}\right)+\ell_{3 t} \ln \left(B / M_{i t-1}\right)+\ell_{4 t} M \text { om }_{i t-1} \\
& +\ell_{5 t} z_{i t-1}+\varepsilon_{i t}
\end{aligned}
$$

Hipotesis Statistik untuk model tersebut adalah

$\mathrm{H}_{0}: \mu_{5 \mathrm{t}}=\ell_{5 t} \quad \mathrm{H}_{1}: \mu_{5 \mathrm{t}} \neq \ell_{5 t}$

\section{Pengujian Asumsi Klasik}

Pengujian asumsi klasik ini diperlukan untuk mengetahui terpenuhi atau tidaknya asumsi yang dipersyaratkan dalam model regresi linear yang menentukan baik tidaknya model penelitian. Pengujian dengan melihat multikolinearitas, homoskedastisitas, normalitas, dan autokorelasi.

\section{HASIL ANALISIS DAN PEMBAHASAN}

\section{1. Statistik Deskriptif}

Berdasarkan kriteria purposive sampling selama periode pembentukan portofolio yaitu Juli 1992 - Juni 2003 maka rata-rata sampel perusahaan selama setahun kurang lebih 103 perusahaan. Dengan total sampel yang digunakan, pembentukan portofolio sebanyak 8 kali selama 12 tahun (Juli 1992 - Juni 2003) menghasilkan $\mathrm{N}$ untuk analisis regresi sebanyak 1152. Data dengan nilai standard skornya pada kisaran 3 sampai 4 dinyatakan sebagai data yang outlier. Data ini kemudian dibuang. Jadi setelah dikurangi dengan data-data yang outlier atau tidak normal maka total $\mathrm{N}$ yang digunakan dalam analisis regresi sebanyak 1069. 
Sampel juga dikelompokkan berdasarkan kondisi pasar (bullish atau bearish). Pengelompokan sampel untuk pengujian hipotesis adalah sebagai berikut: sampel penuh (perioda Juli 1992 - Juni 2003), sub-sampel A (perioda Juli 1992 - Juni 2003 dengan kondisi pasar bullish), dan sub sampel B (perioda Juli 1992 - Juni 2003 dengan kondisi pasar bearish). Dari data-data variabel independen yang diperoleh dari Indonesian Capital Market Directory (ICMD) yaitu beta portofolio, book-to-market (equity per sahre dibagi dengan closing price), size (kapitalisasi pasar), momentum (rata-rata raw return saham selam 12 bulan lalu), dan nilai z (nilai distress risk berdasarkan model yang dikemukakan Likumahwa), serta variabel dependen excess return untuk setiap perusahaan didapatkan nilai statistif deskriptif seperti yang tercantum dalam tabel berikut:

Tabel 1

Nilai Statistik Deskriptif Data

(perioda Juli 1992 - Juni 2003)

Sampel Penuh

\begin{tabular}{lcccccc}
\hline & $\mathbf{R}$ & Beta & Ln Size & LnB/M & Momentum & Z-score \\
\hline $\mathrm{N}$ & 1069 & 1069 & 1069 & 1069 & 1069 & 1069 \\
Minimum & - & 0,08 & 9,67 & $-1,50$ & $-6,50$ & $-0,42$ \\
Maximum & 21,39 & 1,39 & 15,80 & 2,08 & 19,04 & 4,81 \\
Mean & $-18,68$ & 0,75 & 12,44 & 0,02 & 0,98 & 1,38 \\
Std. Deviasi & 9,27 & 0,28 & 1,68 & 0,66 & 4,17 & 0,96 \\
\hline
\end{tabular}

Sub-Sampel A

(Perioda Kondisi Pasar Bullish)

\begin{tabular}{lcrcccc}
\hline & $\mathbf{R}$ & Beta & LnSize & LnB/M & Momentum & Z-score \\
\hline $\mathrm{N}$ & 103 & 103 & 103 & 103 & 103 & 103 \\
Minimum & $-7,76$ & 0,20 & 9,76 & $-1,43$ & $-5,18$ & $-0,25$ \\
Maximum & 21,39 & 1,25 & 15,80 & 1,94 & 18,13 & 4,81 \\
Mean & 6,45 & 0,81 & 12,42 & $-0,15$ & 1,95 & 1,57 \\
Std. Deviasi & 10,74 & 0,26 & 1,70 & 0,70 & 4,21 & 1,27 \\
\hline
\end{tabular}

Sub-Sampel B

(Perioda Kondisi Pasar Bearish)

\begin{tabular}{lcccccc}
\hline & $\mathbf{R}$ & Beta & LnSize & LnB/M & Momentum & Z-score \\
\hline $\mathrm{N}$ & 966 & 966 & 966 & 966 & 966 & 966 \\
Minimum & - & 0,08 & 9,67 & $-1,51$ & $-6,50$ & $-0,42$ \\
Maximum & 16,85 & 1,39 & 15,68 & 2,08 & 19,04 & 2,75 \\
Mean & $-14,21$ & 0,75 & 12,45 & 0,04 & 0,88 & 1,36 \\
Std. Deviasi & 9,18 & 0,28 & 1,67 & 0,65 & 4,15 & 0,92 \\
\hline Sumber: data diolah & & & & &
\end{tabular}


Setiap tahun terbentuk 8 portofolio berdasarkan beta, size, dan B/M dan di-rebalance sebanyak 12 kali sehingga selama perioda pengamatan (Juli 1992 - Jun 2003) total portofolio yang dibentuk selama periode penelitian sebanyak 96 portofolio. Ringkasan masing-masing rata-rata excess return, Beta, Size, B/M, Momentum, dan Distress Risk berdasarkan strategi portofolio yang dibentuk seperti pada tabel dibawah ini:

Tabel 2

Rata-Rata Variabel Berdasarkan Portofolio Yang Dibentuk Atas Dasar Beta, Size, dan B/M

\begin{tabular}{lrrrrrrrr}
\hline & $\mathbf{p} 1$ & $\mathbf{p 2}$ & $\mathbf{p 3}$ & $\mathbf{p 4}$ & $\mathbf{p 5}$ & $\mathbf{p 6}$ & $\mathbf{p 7}$ & $\mathbf{p 8}$ \\
\hline & & & & & & & & \\
$\mathbf{R}$ & -0.16 & -0.17 & -0.16 & -0.16 & -0.16 & -0.16 & -0.15 & -0.16 \\
Beta & 1.06 & 0.9 & 0.81 & 0.79 & 0.79 & 0.82 & 0.63 & 0.55 \\
Size & 13.37 & 14.83 & 10.76 & 11.66 & 11.66 & 13.17 & 10.75 & 11.02 \\
B/M & 1.49 & 0.65 & 2.4 & 1.36 & 1.36 & 1.31 & 1.89 & 1.13 \\
Momentum & 1.74 & 0.41 & 1.34 & 1.1 & 1.1 & 1.14 & 0.41 & 0.69 \\
$\mathbf{Z}$ & 0.94 & 1.87 & 0.98 & 1.37 & 1.37 & 1.09 & 1.16 & 1.59 \\
\hline
\end{tabular}

Sumber: data diolah

\section{2. Pengujian distress risk dapat menjelaskan efek anomali momentum atau return continuation pada return saham}

Setelah portofolio dibentuk berdasarkan prosedur yang ada kemudian kedelapan portofolio tersebut diuji dengan analisis regresi mengunakan model yang telah disebutkan di atas. Koefisien $\gamma_{4}$ yang signifikan menunjukkan bahwa momentum memiliki pengaruh yang positif terhadap return saham, sedangkan koefisien $\gamma_{5}$ menunjukkan bahwa distress risk berpengaruh negatif terhadap return saham sekaligus menunjukkan bahwa distress risk dapat menjelaskan efek dari anomali momentum. Hasil pengujian adalah sebagai berikut:

\begin{tabular}{|c|c|c|c|c|c|c|}
\hline & & & $\begin{array}{r}\text { Tabel } 3 \\
\text { Analisis R }\end{array}$ & & & \\
\hline & $\alpha$ & $\gamma 1$ & $\gamma 2$ & $\gamma 3$ & $\gamma 4$ & $\gamma 5$ \\
\hline (1) & $\begin{array}{c}-7.36 \\
(-3.11)^{\star * *}\end{array}$ & $\begin{array}{c}1.05 \\
(0.96)\end{array}$ & $\begin{array}{c}-0.57 \\
(-2.83)^{\star * *}\end{array}$ & $\begin{array}{c}-2.63 \\
(-5.36)^{* * *}\end{array}$ & & \\
\hline (2) & $\begin{array}{c}-6.99 \\
(-2.99)^{* * *}\end{array}$ & $\begin{array}{c}0.08 \\
(0.08)\end{array}$ & $\begin{array}{c}-0.57 \\
(-2.84)^{\star * *}\end{array}$ & $\begin{array}{c}-2.52 \\
(-5.18)^{\star * *}\end{array}$ & $\begin{array}{c}0.34 \\
(4.97)^{\star * *}\end{array}$ & \\
\hline (3) & $\begin{array}{c}-7.18 \\
(-3.06)^{* * *}\end{array}$ & $\begin{array}{c}0.05 \\
(0.04)\end{array}$ & $\begin{array}{c}-0.57 \\
(-2.65)^{\star * *}\end{array}$ & $\begin{array}{c}-2.69 \\
(-5.09)^{\star * *}\end{array}$ & $\begin{array}{c}0.34 \\
(4.97)^{\star * *}\end{array}$ & $\begin{array}{c}-0.37 \\
(-1.11)\end{array}$ \\
\hline
\end{tabular}

*** signifikan pada $\alpha=1 \%$

Sumber: data diolah

Penambahan variabel momentum tidak mengakibatkan perubahan koefisien dari ketiga variabel yang lain yaitu beta, size, dan B/M dalam menjelaskan return saham. Size dan B/M tetap signifikan dan memiliki pengaruh negatif dalam menjelaskan return saham. Sedangkan beta tetap tidak signifikan dalam menjelaskan return saham. 
Adanya variabel momentum tidak membuat koefisien $\mathrm{B} / \mathrm{M}$ berubah dalam menjelaskan return saham (tetap sebesar $-0,57)$. Berdasarkan hasil pengujian pada model 1a maka terlihat bahwa koefisien $\gamma_{4}$ positif $(0,34)$ dan signifikan $(t=$ 4,97). Hal ini berarti bahwa variabel momentum memiliki pengaruh dalam menjelaskan return saham. Ketika variabel z-score dimasukkan dalam persamaan pricing tampak bahwa koefisien variabel size tetap sebesar $-0,57$ dan tetap signifikan terhadap return saham. Pengaruh B/M terhadap return saham tetap signifikan dan pengaruhnya semakin negatif (koefisien menjadi -2,69 dari yang semula -2,52). Variabel momentum juga tetap signifikan dan koefisiennya tidak berubah (tetap sebesar 0,34 ). Jadi berdasarkan hasil pengujian pada model $1 \mathrm{~b}$ menunjukkan bahwa variabel z sebagai variabel distress risk tidak dapat menjelaskan efek dari anomali momentum. Ini berarti hipotesis pasar efisien yang menyatakan return "abnormal" melawan pasar efisien dan return tersebut merupakan kompensasi yang wajar dari risiko untuk pasar modal di Indonesia tidak terdukung. Jadi, pada pasar modal Indonesia anomali momentum tidak/bukan merupakan kompensasi dari risiko.

\section{3. Pengujian perbedaan hubungan efek momentum dan distress risk pada kondisi bullish market atau bearish market}

Pengujian dilakukan untuk menyelidiki hubungan antara momentum dan financial distress risk pada kondisi ekonomi yang berbeda, yaitu pada saat pasar bullish dan bearish. Pengujian regresi mengunakan model $2 a$ dan $2 b$ dengan sampel yang dibagi menjadi 2 yaitu pada kondisi pasar bullish dan pada kondisi pasar bearish. Koefisien $\mu_{4} \neq \ell_{4}$ yang signifikan menunjukkan bahwa pengaruh momentum terhadap return saham pada kondisi pasar bullish dan bearish tidak berbeda. Begitu juga dengan koefisien $\mu_{5} \neq \ell_{5}$ yang signifikan menunjukkan bahwa distress risk dapat menjelaskan efek anomali momentum pada pasar bullish berbeda dengan kondisi pasar ketika bearish. Hasil pengujian adalah sebagai berikut:

$$
\begin{aligned}
& R-R_{f}=\alpha_{i t}+\mu_{1 t} \beta_{i t-1}+\mu_{2 t} \ln \left(\text { size }_{i t-1}\right)+\mu_{3 t} \ln \left(B / M_{i t-1}\right)+\mu_{4 t} M_{i t}{ }_{i t-1}+\mu_{5 t} z_{i t-1}+\varepsilon_{i} \\
& R-R_{f}=\alpha_{i t}+\ell_{1 t} \beta_{i t-1}+\ell_{2 t} \ln \left(\text { size }_{i t-1}\right)+\ell_{3 t} \ln \left(B / M_{i t-1}\right)+\ell_{4 t} \text { Mom }_{i t-1}+\ell_{5 t} z_{i t-1}+\varepsilon_{i t}
\end{aligned}
$$

Tabel 4

Hasil Analisis Regresi

A. Kondisi Pasar Bullish

\begin{tabular}{ccccccc}
\hline & $\alpha$ & $\gamma 1$ & $\gamma 2$ & $\gamma 3$ & $\gamma 4$ & $\gamma 5$ \\
\hline (1) & -33.21 & -2.67 & 2.89 & 6.86 & & \\
& $(-4.49)^{* * *}$ & $(-0.70)$ & $(4.55)^{* * *}$ & $(4.74)^{* * *}$ & & \\
& & & & & & \\
$(2)$ & -25.05 & -6.15 & 2.27 & 6.48 & 1.19 & \\
& $(-3.82)^{* * *}$ & $(-1.85)$ & $(4.06)^{* * *}$ & $(5.16)^{* * *}$ & $(5.85)^{* * *}$ & \\
& & & & & & \\
(3) & -25.09 & -6.17 & 2.3 & 7.12 & 1.22 & -2.09 \\
& $(-3.83)^{* * *}$ & $(-1.86)$ & $(4.11)^{* * *}$ & $(5.08)^{* *}$ & $(5.94)^{* * *}$ & $(-2.74)$ \\
\hline
\end{tabular}


B. Kondisi Pasar Bearish

\begin{tabular}{|c|c|c|c|c|c|c|}
\hline & $\alpha$ & $\gamma 1$ & $\gamma 2$ & $\gamma 3$ & $\gamma 4$ & $\gamma 5$ \\
\hline (1) & $\begin{array}{c}-5.03 \\
(-2.04)^{\star *}\end{array}$ & $\begin{array}{c}0.64 \\
(0.56)\end{array}$ & $\begin{array}{c}-0.77 \\
(-3.63)^{\star * *}\end{array}$ & $\begin{array}{c}-2.99 \\
(-5.74)^{\star * *}\end{array}$ & & \\
\hline (2) & $\begin{array}{c}-4.95 \\
(-2.01)^{\star *}\end{array}$ & $\begin{array}{c}0.03 \\
(0.02)\end{array}$ & $\begin{array}{c}-0.75 \\
(-3.58)^{* * *}\end{array}$ & $\begin{array}{c}-2.91 \\
(-5.60)^{\star * *}\end{array}$ & $\begin{array}{c}0.22 \\
(3.10)^{\star * *}\end{array}$ & \\
\hline (3) & $\begin{array}{c}-5.07 \\
(-2.05)^{\star *}\end{array}$ & $\begin{array}{l}-0.007 \\
(-0.01) \\
\end{array}$ & $\begin{array}{c}-0.75 \\
(-3.59)^{\star * *}\end{array}$ & $\begin{array}{c}-3.02 \\
(-5.38)^{\star * *}\end{array}$ & $\begin{array}{c}0.22 \\
(3.11)^{\star * *}\end{array}$ & $\begin{array}{r}-0.15 \\
(-0.40) \\
\end{array}$ \\
\hline
\end{tabular}

Dari tabel 4. terlihat bahwa selama kondisi pasar bullish maupun bearish koefisien size dan B/M tetap signifikan dalam menjelaskan return saham. Selama kondisi pasar bullish pengaruh size dan B/M positif terhadap return saham. Sebaliknya selama kondisi pasar bearish, pengaruh size dan B/M negative terhadap return saham. Sedangkan variabel beta baik kondisi pasar bullish maupun pasar bearish tetap tidak signifikan dalam menjelaskan return saham. Penambahan variabel momentum pada model 2a tidak terlalu mempengaruhi variable size dan B/M dalam menjelaskan return saham. Koefisien size dan beta tetap signifikan dan memiliki pengaruh positif pada return saham. Berdasarkan pengujian dengan sampel yang dibagi dua berdasarkan kondisi pasar terlihat bahwa momentum signifikan dan berpengaruh positif pada return saham baik kondisi pasar bullish ( $\mu_{4}=1,10$ dengan $t$ $=5,85)$ maupun pasar bearish $\left(\ell_{4}=0,02\right.$ dengan $\left.t=3,10\right)$. Hal ini menunjukkan bahwa tidak terdapat perbedaan pengaruh kondisi pasar ketika variabel momentum dimasukkan atau dikeluarkan dalam persahaan pricing. Ketika distress risk dimasukkan pada persaamaan pricing seperti model $2 \mathrm{~b}$, hasil pengujian menunjukkan bahwa variabel distress risk tetap tidak signifikan baik pada kondisi pasar bullish maupun bearish. Jadi distress risk tidak dapat menggantikan atau menjelaskan efek anomali momentum baik pada kondisi bullish maupun bearish. Penambahan variable $z$ hanya mengakibatkan koefisien momentum bertambah tinggi ketika kondisi pasar bullish sedangkan tetap pada kondisi bearish. Begitu pula dengan variabel size, B/M yang tetap signifikan, positif, dan bertambah tinggi (dibandingkan ketika variable distress risk tidak dimasukkan dalam persamaan pricing) pada kondisi bullish. Sedangkan pada kondisi bearish, masuknya variabel distress risk tidak mengubah koefisien size (koefisiennya tetap $-0,75$ ) tetapi hanya mengubah koefisien B/M (dari -2,91 menjadi $-3,02$ ) tetapi tetap signifikan terhadap return saham.

Berdasarkan hasil tampak bahwa tidak ada perbedaan pengaruh distress risk terhadap efek momentum pada kondisi pasar bullish maupun pada kondisi pasar bearish. Walaupun distress risk tidak dapat menggantikan efek dari anomali momentum, namun pada kondisi bullish adanya variabel distress risk menyebabkan koefisien momentum lebih tinggi (dari 1,19 menjadi 1,22) dibandingkan pada kondisi bearish. Karena pada kondisi bearish, penambahan atau tidak variabel distress risk pada persamaan pricing tidak mengubah koefisien momentum (tetap sebesar 0,22 ). Salah satu penjelasan yang dikemukakan adalah bahwa pada kondisi pasar bullish cenderung tingkat resiko lebih tinggi dibandingkan ketika kondisi pasar bearish. Hal ini menyebabkan pada kondisi bullish perusahaan cenderung dapat mengalami distress lebih besar dari pada kondisi bearish. Pergerakan saham yang cukup volatile pada pasar bullish dapat menyebabkan adanya abnormal return dan mengakibatkan anomali momentum semakin besar dibandingkan kondisi pasar yang bearish di mana pergerakan sahamnya lebih stabil. 
Berdasarkan pengujian maka terdapat penolakan pada $\mathrm{H} 2$ dan justru memunculkan hasil penemuan bahwa pada kondisi pasar bullish, koefisien size dan B/M positif dan signifikan ketika momentum dan distress risk dimasukkan dalam persamaan pricing. Koefisien size maupun B/M juga mengalami perubahaan ketika momentum dan distress risk dimasukkan dalam persamaan pricing. Sedangkan pada kondisi pasar bearish, koefisien size dan B/M negatif dan signifikan ketika momentum dan distress risk dimasukkan dalam persamaan pricing. Hanya koefisien B/M yang mengalami perubahan sedangkan koefisien size tetap ketika momentum dan distress risk dimasukkan dalam persamaan pricing.

\section{PENUTUP}

Berdasarkan hasil analisis data dan pengujian hipotesis dapat diambil simpulan sebagai berikut (1) ditemukan bahwa distress risk tidak dapat menjelaskan efek anomali momentum atau return continuation pada return saham. Sehingga efek anomali momentum tidak dapat dijelaskan/digantikan oleh distress risk pada pasar modal Indonesia. Hal tersebut menunjukkan efek anomali momentum bukan merupakan faktor risiko; (2) tidak terdapat perbedaan pengaruh distress risk terhadap efek momentum pada kondisi bullish market atau bearish market. Distress risk juga tidak dapat menjelaskan/mengantikan efek anomali momentum atau return continuation baik pada kondisi pasar bearish maupun pada kondisi pasar bullish; (3) ditemukan hasil yang menunjukkan bahwa adanya variabel distress risk dan momentum pada persamaan pricing membuat variabel size dan B/M berpengaruh positif terhadap return saham saat kondisi pasar bullish dan berpengaruh negatif terhadap return saham saat kondisi pasar bearish. Koefisien size tidak berubah pada kondisi bearish ketika momentum dan distress risk dimasukkan dalam persamaan pricing.

Beberapa implikasi penting yang dapat diambil dan dapat dipergunakan sebagai bahwan masukan maupun pertimbangan baik bagi para investor maupun perusahaan yang menerbitkan saham adalah bahwa pada pasar modal Indonesia menunjukkan momentum bukan merupakan faktor risiko sehingga investor maupun perusahaan harus lebih berhati-hati dalam menginterpretasikan pergerakan harga dari saham-saham tersebut. Para praktisi investasi juga tidak dapat menggunakan momentum sebagai faktor distress risk baik ketika kondisi pasar bullish atau bearish. Walaupun kecil, informasi mengenai momentum dan distress risk membuat variabel three-factorCAPM lebih signifikan dalam menjelaskan return saham. Hal ini dapat membuat investor lebih medapatkan gambaran tentang peluang investasi yang ada, sehingga dapat menentukan alternatif investasi yang lebih menguntungkan untuk dana yang dimilikinya. Sedangkan para akademisi di bidang ekonomi finansial, khususnya bidang investasi perlu lebih mencermati dan meneliti lebih jauh lagi faktor apa yang sebenarnya dapat menjelaskan efek dari anomali momentum. Hal ini untuk memperkuat dan mengembangkan teori yang ada agar semakin dapat memberikan alternatif dasar-dasar yang dapat digunakan sebagai bahan pengambilan keputusan investasi di pasar saham.

\section{DAFTAR PUSTAKA}

Agarwal, Vineet dan Richard Taffler, (2005), "Does the Financial Distress Factor Drive the Momentum Anomaly?" Version Vol. 9 Mo. 2, 9 February. Paper presented in the Financial Faculty Seminar Series at City University Business School London. pp.1-35.

Ang, A. dan J. Chen, (2002), "Asymmetric Correlations of Equity Portofolio", Journal of Financial Economics 63. pp.443-494.

Barberis, N., A. Shleifer, dan R. Vishny, (1998), "A Model of Incestment Sentiment", Journal of Financial Economics 49, pp.307-343.

Berk, J.B., R. Green, dan V. Naik, (1999), "Optimal Investment, Growth Options, and Security Returns" Journal of Finance Vol. 54 No. 5, pp.1553-1607. 
Brigham, Eugene F. dan Philip R. Daves (2004), Intermediate Financial Management. $8^{\text {th }}$ edition. Thomson, SouthWestern.

Campbell, John Y., Jens Hilscher, dan Jan Szilagyi, (2004), In Search of Distress Risk, October.

Concard, J. dan G. Kaul, (1998), "An Anatomy of Trading Strategies", Review of Financial Studies 11 pp.489-519.

DeBondt, Werner F.M. dan Richard Thaler, (1985), "Does the Stock Market Overreact? The Journal of Finance. Vol. 11 No. 3, July.

Fama, E. F. dan K. R. French, (1992), The Cross-Sectional of Expected Stocks Returns, Journal of Finance. 47, pp.427-465.

Fama, E. F. dan K. R. French, (1993), "Common Risk Factors in the Return on Stocks and Bonds", Journal of Financial Economics 33 pp.3-56.

Fama, E. F. dan K. R. French, (1996), "Multifactor Explanations of Assets Pricing Anomalies", Journal of Finance. 51. pp. 55-84.

Griffin, J., dan L. Lemmon, (2002), "Book-to-Market Equity, Distress Risk, and Stock Return", Journal of Finance 57 pp.2317-2336.

Griffin, J., X. Ji, dan J.S. Martin, (2003), "Momentum Investing and Business Cycle Risk: Evidence From Pole to Pole", Journal of Finance 59 pp.2515-2547.

Hong, H. dan J. Stein, (1999), "A Unified Theory of Underreaction, Momentum Trading and Overreaction in Assets Markets", Journal of Finance. 54. pp.2143-2184.

Hong, Dong dan Charles Lee, (2003), Earnings Momentum in International Markets. Bhaskaran Swaminathan Cornell University. February.

Jagannathan, R. dan Z. Wang, (1996), "The Conditional CAPM and the Cross-Section of Expected Returns", Journal of Finance 51 pp.3-53.

Jegadeesh, N. dan S. Titman, (1993), "Return to Buying Winners and Selling Losers: Implication for Stock Market Efficiency", Journal of Finance. 48. pp.65-91.

Jones, C.P., (2004), Investment: Analysis and Management. $9^{\text {th }}$ edition. John Willey \& Sons, New York.

Kahl, Matthias, (2002), "Economic Distress, Financial Distress, and Dynamic Liquidation”, The Journal of Finance Vol.57 No.1, February.

Moskowitz, T. dan Grinblatt, (1999), "Do Industries Explain Momentum”, Journal of Finance 54 pp.1249-1290.

$\mathrm{Ng}$, Jeffrey, (2004), Distress Risk Information in Accruals. The Wharton Scholl University of Pennsylvania. 1303 Steinberg-Dietrich Hall. 30 December.

Tandelilin, Eduardus, (2001), "Beta pada Pasar Bullish dan Bearish: Studi Empiris di Bursa Efek Jakarta. Jurnal Ekonomi \& Bisnis Indonesia. 16(3). pp.261-272.

Zhang, L. dan R. Petkova, (2005), "Is Value Riskier than Growth? Journal of Financial Economics. pp.1-22. 